\title{
Enzyme Assisted Extraction of GAC Oil (Momordica cochinchinensis Spreng) from Dried Aril
}

\author{
Tran Thi Yen Nhi, Dang Quoc Tuan* \\ Department of Food Technology, International University, Vietnam National University -Ho Chi Minh City, Vietnam \\ Email address \\ dqtuan@hcmiu.edu.vn (D. Q. Tuan)
}

\section{To cite this article:}

Tran Thi Yen Nhi, Dang Quoc Tuan. Enzyme Assisted Extraction of GAC Oil (Momordica cochinchinensis Spreng) from Dried Aril. Journal of Food and Nutrition Sciences. Vol. 4, No. 1, 2016, pp. 1-6. doi: 10.11648/j.jfns.20160401.11

\begin{abstract}
The purpose of this study was to improve the oil yield extracted from Gac fruit aril (Momordica cochinchinensis Spreng) by applying hydrolytic enzyme and to evaluate functional properties of the extracted Gac oil as influenced by different enzyme concentrations, incubation times and drying temperatures. Fresh Gac aril was treated with commercial enzyme (Viscozyme L) (0-0.2\%) for a period of time $(40-120 \mathrm{~min})$, dried at a certain temperature $\left(40-70^{\circ} \mathrm{C}\right)$ and then extracted with hexane for oil recovery. The best conditions for Gac aril extraction were $0.15 \%$ enzyme concentration, 100 min incubation time and drying temperature $60^{\circ} \mathrm{C}$. Under these conditions, the oil recovery rate was of $96.39 \%$ with the total carotenoid content of $196.47 \mathrm{mg} / 100 \mathrm{~g}$. The resulted oil recovery rate $(89.74 \%)$ and total carotenoid content $(132.16 \mathrm{mg} / 100 \mathrm{~g}) \mathrm{were}$ significantly higher than those from the oil without enzymatic treatment. The peroxide value $(8.73 \mathrm{meqO} / \mathrm{kg})$ and free fatty acid value $(3.58 \mathrm{mg} \mathrm{KOH} / \mathrm{g}$ oil) of the extracted Gac oil was comparable with oil by other methods. The Gac oil was rich in un-saturated fatty acids (oleic acid $48.99 \%$, linoleic acid $21.09 \%$ and linolenic acid $0.86 \%$ ), high in palmitic acid (24.18\%) but low in stearic acid (3.52\%). Application of Viscozyme L helped to increase significantly the oil recovery yield and total carotenoid content in oil, meanwhile, the oil was of good quality in terms of oxidative stability.
\end{abstract}

Keywords: Enzyme-Assisted Extraction, Free Fatty Acid, Gac Oil, Peroxide Value, Total Carotenoid

\section{Introduction}

Gac fruit (Momordica Cochinchinensis Spreng) is botanically classified to the Cucurbitaceae family. Gac is one of the traditional plants that is mainly grown in South East Asia, particularly in Vietnam. Gac fruit aril contains 102 $\mathrm{mg} / \mathrm{g}$ of edible oil. It maintains high nutritional values and could be used both as a final food and food ingredient [1]. It contains exceptionally high level of carotenoids in comparison with other fruits and vegetables, especially $\beta$ carotene and lycopene. Moreover, it was reported that Gac fruit oil also contained large amount of $\alpha$-tocopherols (vitamin E), polyphenol, flavonoid compounds and rich in fatty acids composition especially unsaturated essential fatty acids [2-7]. In addition, a portion of unsaturated fatty acid can be up to $70 \%$ of total fatty acids, while half of those are polyunsaturated [8].

In order to improve the yield and quality of natural products including oils, flavouring and bioactives from plant materials, application of enzymes has been extensively investigated. Pre-treatments of the materials with hydrolytic enzymes such as cellulase, xyloglucanase, pectinase, etc. to hydrolyze and degrade the cell wall as well as the polysaccharide network surrounding the cell have proved effective in enhancing the release of intracellular contents by extraction [9-10].

The commercial enzyme "Viscozyme L" belongs to a cellulase enzyme class, it includes arabanase, cellulase, $\beta-$ glucanase, hemicellulase and xylanase. With this type of enzyme formulation, Viscozyme L helped to increase the oil extraction yield for hemp seed oil [11]. It enhanced the total carotenoid content of marigold flower [12]. Enzyme assisted solvent extraction helped to increase the oil yield of soybean seed by more than $8-10 \%$ and up to $4 \%$ with sunflower oil. In canola oil extraction, the oil yield increased with the use of carbohydrase while the extraction time was significantly reduced [13-14].

However, application of Viscozyme L in Gac oil extraction has not been reported. Therefore, the overall goal of this study is to improve the oil yield extracted from Gac fruit aril by applying a hydrolytic enzyme. The research covers the investigation of: (1) the effect of enzyme concentration; (2) 
the effect of enzyme incubation time; and (3) the effect of drying temperature on the extraction yield; and (4) evaluation of functional properties of the extracted oil.

\section{Materials and Methods}

\subsection{Materials and Chemicals}

All solvents/chemicals (hexane $(>=96 \%)$ used for experiment were analytical grade and purchased from local agents of Merck, Sigma or Chinese supplier in Vietnam. $\beta$ carotene (synthetic type I) was purchased from SigmaAldrich, was used as standard.

Gac fruits were purchased from local markets in Tây Ninh Province, Viet Nam. Fresh Gac fruit aril consisted of one third of Gac fruit weight with color from orange to red. The fresh aril containing seed was manually separated and stored at $-20^{\circ} \mathrm{C}$ until use.

Viscozyme L was obtained from a local agent of Novozymes in Viet Nam. Viscozyme L contained betaglucanase (endo-1, 3(4)-) from Aspergillus aculeatus, with the following specifications: claimed activity (100 FBG/g), density $1.21(\mathrm{~g} / \mathrm{mL})$, optimum temperature $\left(35-55^{\circ} \mathrm{C}\right)$ and $\mathrm{pH}$ (4-5).

\subsection{Experimental Design}

Fresh Gac aril were treated with different enzyme concentrations $(0.0,0.05,0.1,0.15$ and $0.2 \%)$ on Gac aril weight basis (Enzyme/Substrate $-\mathrm{E} / \mathrm{S}$ ) at $50^{\circ} \mathrm{C}$ for different incubation times $(40,60,80,100$ and $120 \mathrm{~min})$. After that, the mixture was placed in water bath at $90^{\circ} \mathrm{C}$ for $5 \mathrm{~min}$ to inactivate enzyme and cooled down to room temperature. The enzyme-treated Gac aril was dried at different temperatures $\left(40,50,60\right.$ and $\left.70^{\circ} \mathrm{C}\right)$ for a specific time until a $10 \%$ moisture content. The dried Gac aril and hexane then were mixed in a ratio $1: 20(\mathrm{w} / \mathrm{v})$ in a $250 \mathrm{~mL}$ Erlenmeyer flask and incubated on the magnetic stirring $(150 \mathrm{rpm})$ at room temperature overnight. The extraction with n-hexane was repeated for second time in a ratio 1:10 (w/v). Before each extraction, the Erlenmeyer flasks containing a mixture of dried Gac aril and hexane were sonicated for $10 \mathrm{~min}$ at the $40 \mathrm{kHz}$ frequency. After solvent extraction, the mixture was filtered and filtrates were combined. After that, the oil was separated from solvent in a rotary evaporator at $50^{\circ} \mathrm{C}$. The crude oil was stored for further physiochemical analysis. The control sample was the sample without the use of enzyme.

\subsection{Physico-Chemical Analysis}

\section{$\%$ Oil recovery}

The oil amount obtained from each treatment is used to calculate the percentage of oil recovery based on the initial oil in the sample estimated using Soxhlet method (AOAC, 1990).

$$
\% \text { Oil recovery }=\frac{\text { Weight }(\mathrm{g}) \text { of oil extracted using enzyme } \times 100}{\text { Weight }(\mathrm{g}) \text { of oil extracted by Soxhlet method }}
$$

\section{Total carotenoid content}

Total carotenoid content was determined following the method described by Cenkowski et al. [15]. 0.1g extracted oil were weighed and diluted with $10 \mathrm{ml}$ hexane, mixed well and then measured at $460 \mathrm{~nm}$ with a spectrophotometer (Genesys 10S, USA) against a blank of pure hexane. To construct a standard curve, a stock solution was prepared by dissolving $0.1 \mathrm{~g}$ of $\beta$-carotene in $100 \mathrm{~mL}$ hexane. Aliquots were taken from this solution and diluted to five different concentrations. The amount of carotenoids was interpolated from the standard curve and expressed in $\mathrm{mg} / 100 \mathrm{~g} \quad \beta$-carotene equivalents.

Methods used for determination of peroxide value, free fatty acid value and fatty acid composition were from ISO 03969:2001, ISO 00660: 1996 and GC-ISO/CD 5509:94, respectively.

\subsection{Statistical Analysis}

All treatments were conducted in triplicates and the statistical analysis (ANOVA) was performed by using standard SPSS version 16.0, on the level of significance $\mathrm{P}<0.05$.

\section{Results and Discussion}

\subsection{Effect of Enzyme Concentration on Oil Yield and Total Carotenoid Content of Gac Oil}

The effect of enzyme concentration on the oil recovery and total carotenoid content was significant. As showed in Fig. 1a, when enzyme concentration increased, the oil recovery percentage increased considerably. The highest oil recovery $97.48 \%$ was achieved at $0.2 \% \mathrm{E} / \mathrm{S}$ as compared to other enzyme concentrations. However, there was no significant difference in $\%$ oil recovery between two enzyme concentrations 0.15 and $0.2 \% \mathrm{E} / \mathrm{S}(96.39 \%$ and $97.48 \%$, respectively). It can be explained that cellulolytic enzyme helped in breaking down the cellular structures to obtain a greater permeability of the cell walls, so higher oil was extracted considerably [16]. Nevertheless, if the enzyme concentration was too high compared with the substrates or if enzyme had hydrolyzed almost all the substrates, the enzyme activity would not show any significant effect on oil recovery.

Similar trend was observed in Fig. 1b, where the total carotenoid increased in from $132.16 \mathrm{mg} / 100 \mathrm{~g}$ to 207.21 $\mathrm{mg} / 100 \mathrm{~g}$ as the enzyme concentration increased from 0.0 to $0.2 \% \mathrm{E} / \mathrm{S}$, an increase by $75.05 \mathrm{mg} / 100 \mathrm{~g}$ in the total carotenoid content. It was observed that there was a strong correlation between oil yield and total carotenoid content [17]. Due to its relatively nonpolar structure, $\beta$-carotene would dissolve better in oil. It meant that when the oil yield increased, the total carotenoid content was also higher. Meanwhile, the total carotenoid content of the resulted oil with 0.15 and $0.2 \%$ enzyme concentration was not significantly different (196.47 $\mathrm{mg} / 100 \mathrm{~g}$ and 207.21 $\mathrm{mg} / 100 \mathrm{~g}$, respectively). It was mentioned that total 
carotenoid content in the extracts from marigold flower between 0.1 and $1 \% \mathrm{E} / \mathrm{S}$ enzyme concentration showed an insignificant difference, simply due to substrate limitation, where enzyme concentration was too high as compared to substrates [12]. The obtained results provided evidence that the Gac oil extraction should be conducted at $0.15 \% \mathrm{E} / \mathrm{S}$ enzyme concentration to obtain the oil with high carotenoid content.

\subsection{Effect of Incubation Duration on Oil Yield and Total Carotenoid Content of Gac Oil}

Fig. 2a showed that longer incubation time of enzyme resulted in higher oil extraction recovery percentage (at 80 , 100 and $120 \mathrm{~min}$, oil recovery reached to $92.63,96.39$ and $97.12 \%$, respectively), however, there was no significant difference in oil recovery between 100 and $120 \mathrm{~min}$ incubation time. As for total carotenoid content, following the trend of Gac oil recovery, total carotenoid content was also increased with the increased incubation time (Fig. 2b). From $40 \mathrm{~min}$ to $120 \mathrm{~min}$ incubation time, the carotene content increased significantly, $149.81 \mathrm{mg} / 100 \mathrm{~g}$ and 200.93 $\mathrm{mg} / 100 \mathrm{~g}$, respectively. However, the resulted total carotenoid contents at 100 and $120 \mathrm{~min}$ incubation time were not showed any significant increase.

That can be explained that the prolonged incubation time would support the oil extraction by enhancing permeability of cell wall and releasing more oil. Nevertheless, continuing to increase the incubation time would not show the significant increase in oil. It may be due to the decrease of enzyme activity over time or the exhausting of substrate [18]. Besides, the higher percentage oil extracted would hinder and restrict the enzyme activity to catalyze more substrate, hence, the oil recovery would not increase significantly. As mentioned, the $\beta$-carotene can dissolve well in oil. Therefore, if the incubation time of enzyme happened too long, the oil recovery would almost insignificantly increase due to the exhaustion of Gac aril substrate and the inactivation of enzyme. So that, the total carotenoid content was not significantly different. This result was also consistent with other published reports [12], [19].

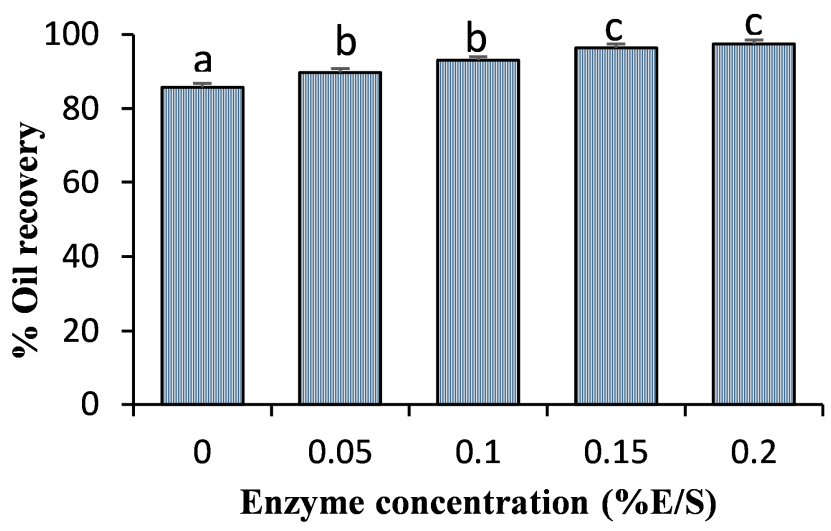

(a)

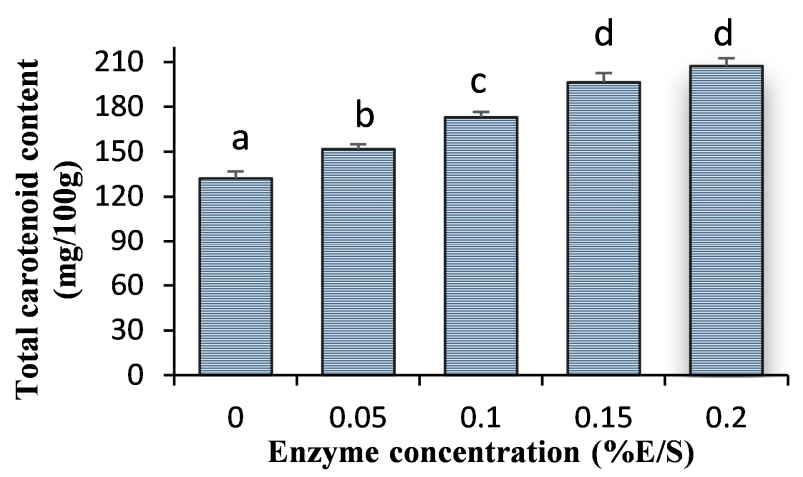

(b)

Figure 1. \% oil recovery (a) and total carotenoid content (b) of Gac oil at different enzyme concentrations.

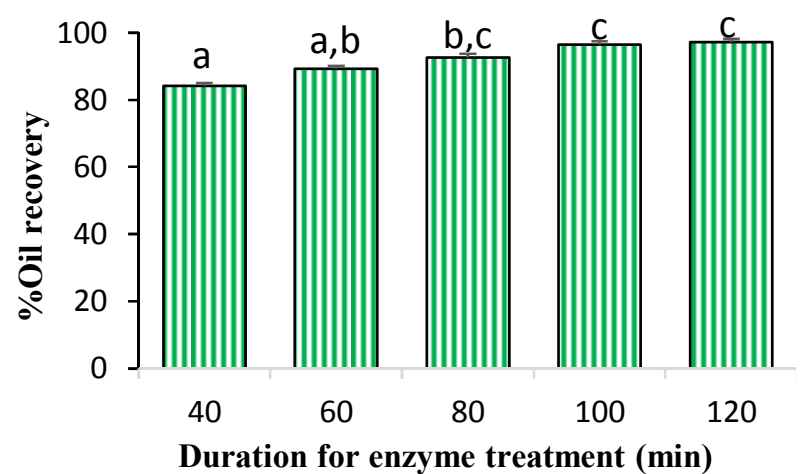

(a)

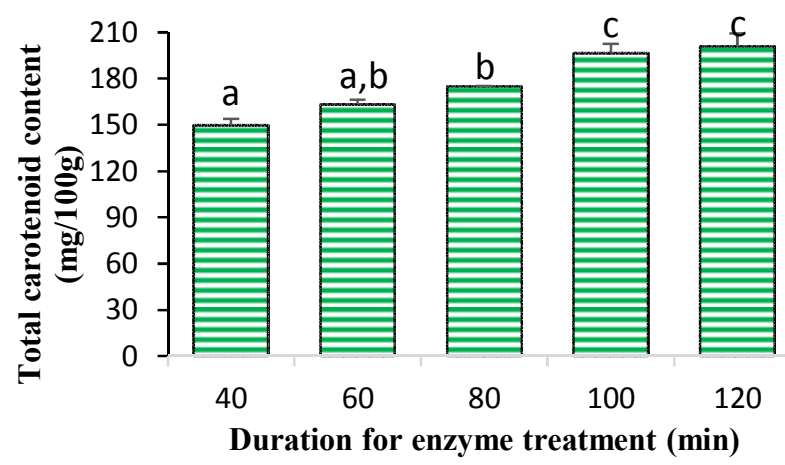

(b)

Figure 2. \% oil recovery (a) and total carotenoid content (b) of Gac oil at different incubation times.

\subsection{Effect of Drying Temperature on Oil Yield and Total Carotenoid Content of Gac Oil}

As shown in Fig. 3, drying temperature had an insignificant effect on the \% oil recovery, however, it showed a significant effect on the total carotenoid content in oil.

Fig. 3a shows that oil recovery increased insignificantly from 40 to $60^{\circ} \mathrm{C}, 93.61$ to $96.39 \%$, respectively reduced a little to $94.72 \%$ at the drying temperature $70^{\circ} \mathrm{C}$. There was required for longer drying time at $40^{\circ} \mathrm{C}$, so that, it would affect negatively on $\%$ oil recovery because of the growth of fungi and the oxidation of oil [20]. At drying temperature higher than $60^{\circ} \mathrm{C}$, some volatile oil compounds would be lost 
and it affected negatively on the oil recovery of Gac aril. Other findings, which were done on Jatropha curcas $L$. kernel, were in agreement with this report [21].

Fig. $3 \mathrm{~b}$ illustrates that the carotene content in the oil obtained from aril dried at $50^{\circ} \mathrm{C}$ and $60^{\circ} \mathrm{C}(198.71$ and $196.47 \mathrm{mg} / 100 \mathrm{~g}$, respectively) were significantly higher than $40^{\circ} \mathrm{C}$ and $70^{\circ} \mathrm{C}(150.10$ and $150.37 \mathrm{mg} / 100 \mathrm{~g}$, respectively). With the conjugated polyene chain that specifically presented for carotenoid structure, $\beta$-carotene could easily be degraded with various factors such as air, light, heat, etc. [22]. Drying Gac aril at $40^{\circ} \mathrm{C}$ required a long period of time, hence, the carotenoid content would be lost considerably.

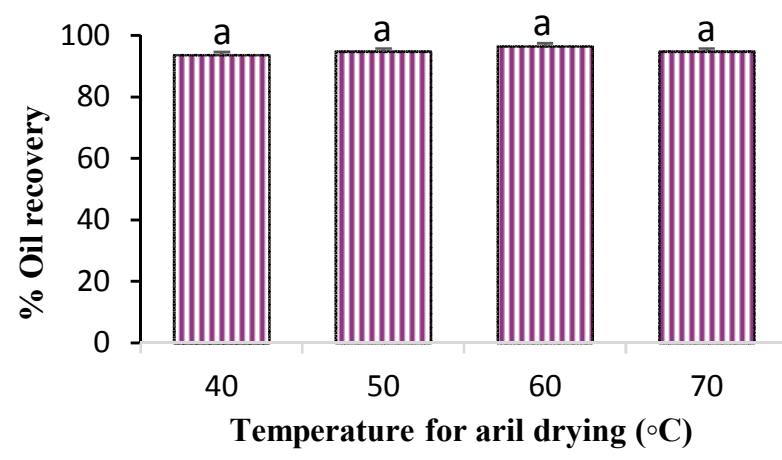

(a)

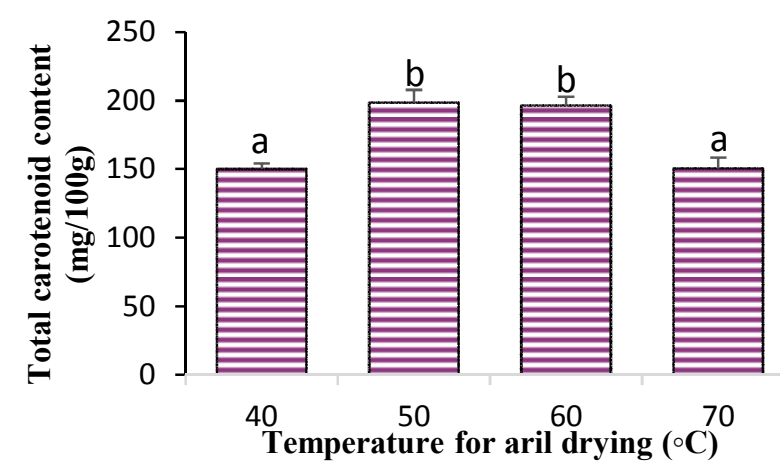

(b)

Figure 3. \% oil recovery (a) and total carotenoid content (b) of Gac oil at different drying temperatures.

Drying at $70^{\circ} \mathrm{C}$ could shorten the drying time, nevertheless, the higher temperature would accelerate the lipid oxidation, causing loss in total carotenoid content. The highest carotene content was at $50^{\circ} \mathrm{C}$, but there was not significantly higher than a $60^{\circ} \mathrm{C}(196.47 \mathrm{mg} / 100 \mathrm{~g})$.

The different level of carotene content could be due to the experiment materials as well as the difference in the extraction process. The $\beta$-carotene content can be varied with many factors such as season, cultivar condition, storage condition time, harvest time, ripened level, etc. [6]. In this study, air drying process in oven might greatly reduce the carotene content in Gac aril.

\subsection{Peroxide Value}

Peroxide value (PV) is one of the important values which can show the initial oxidation level causing rancidity in vegetable oil by measuring the quantity of hydroperoxides in the oil, resulted from the reaction between oxygen and unsaturated fatty acids. Table 1 indicated that PV of the extracted oil $\left(8.73 \mathrm{meqO}_{2} / \mathrm{kg}\right)$ was still comparably higher in comparison with other extraction methods. The reasons for the increased peroxide value in this experiment might be due to the high drying temperature and long drying period around $16 \mathrm{~h}$ [23] as well as long time extraction with hexane (up to $36 \mathrm{~h}$ ). However, it was still lower than PV of oil extracted by Soxhlet method in which the solvent was continuously heated up during extraction [24]. In comparison to the maximum peroxide value Codex STAN 19-1981, the resulted oil was still stable toward oil oxidation.

\subsection{Free Fatty Acid Value}

Free fatty acid (FFA) values represent for triglyceride hydrolysis in fat and oil. The individual free fatty acids are liberated and make the oil slightly acidic [25]. As can be seen from Table 2, the FFA value of this oil was $3.58 \mathrm{mg} \mathrm{KOH} / \mathrm{g}$ or expressed as $1.8 \%$ as oleic acid, and it was higher in comparison with the oil from Soxhlet extraction, cold pressing and microwave assisted cold press. The reason for this phenomenon is that the long extraction time (36 h), organic solvent (n-hexane) and also long air drying time, it accelerated the hydrolysis of triglycerides to free fatty acids causing rancidity in oil and also reduce the physiological quality of oil [23], [26]. On the other hand, the oil in this study still had lower FFA value in comparison to the oil with hexane extraction [27].

Table 1. Peroxide value of Gac oil obtained by different extraction methods.

\begin{tabular}{lll}
\hline Extraction method & $\begin{array}{l}\text { Peroxide value } \\
\left(\mathbf{m e q} \mathbf{O}_{2} / \mathbf{k g}\right)\end{array}$ & Sources \\
\hline Enzyme assisted hexane extraction & 8.73 & This study \\
Microwave assisted cold press & 1.80 & {$[24]$} \\
Soxhlet extraction & 33.54 & {$[24]$} \\
Solvent extraction & 5.40 & {$[27]$} \\
Cold pressing & 7.70 & {$[24]$} \\
\hline
\end{tabular}

Table 2. Free fatty acid value of Gac oil obtained by different extraction methods.

\begin{tabular}{lll}
\hline Extraction method & $\begin{array}{l}\text { Free fatty acid } \\
\text { value }(\mathbf{m g ~ K O H} / \mathbf{g})\end{array}$ & Sources \\
\hline Enzyme assisted hexane extraction & 3.58 & This study \\
Microwave assisted cold press & 0.69 & {$[24]$} \\
Soxhlet extraction & 2.19 & {$[24]$} \\
Solvent extraction & 4.80 & {$[27]$} \\
Cold pressing & 1.80 & {$[24]$} \\
\hline
\end{tabular}

This is because the high heat during extraction process was applied up to $50-55^{\circ} \mathrm{C}$, thus, their PV values had a greater oxidation rate than the resulted oil in this study. Compared to FFA value in Codex STAN 19-1981 standard for non-refined oil, with $3.58 \mathrm{mg} \mathrm{KOH} / \mathrm{g}$, the oil from this study was quite stable to triglyceride hydrolysis. 


\subsection{Fatty Acid Composition}

As can be seen from Table 3, the percentage of unsaturated fatty acids was much higher than saturated fatty acid. The Gac oil extracted from this study was rich in palmitic acid (C16:0), and also oleic acid (C18:1) and linoleic acid (C18:2).

In terms of saturated fatty acids, the total percentage saturated fatty acid obtained from this study (28.62\%) was higher than solvent extraction, but was still lower than Soxhlet extraction, microwave assisted extraction and hydraulic pressing. Especially, the \% of longer chain saturated fatty acid (stearic acid) was much lower than the $\%$ of shorter chain saturated fatty acid (palmitic acid).

Moreover, with the application of Viscozyme L on oil extraction, the resulted oil obtained five more saturated fatty acids as compared to previous studies, lauric, pentadecanoic, arachidic, docosanoic and tetracosanoic acid (0.02, 0.1, 0.21, 0.03 and $0.04 \%$, respectively).

The total percentage unsaturated fatty acids in the resulted oil of this study was $71.38 \%$, still higher than that in the oil by microwave drying before pressing $(67.75 \%)$, hydraulic pressing (55.74\%) and Soxhlet extraction (56.7\%), but lower than the oil by solvent extraction $(73.94 \%)$. In addition, the dominant fatty acids of oil from this study was oleic acid (48.99\%), linoleic acid (21.09\%) and linolenic acid (0.86\%). It is said that the high percentage oleic acid and linoleic acid in dietary intake can contribute to human health.

Table 3. FAME composition of Gac oil (\% total FAMEs) obtained by different extraction methodsFatty acid composition.

\begin{tabular}{llllll}
\hline & \% in oil & & & & \\
\cline { 2 - 6 } & This study & Solvent Extraction [27] & $\begin{array}{l}\text { Microwave-assisted } \\
\text { cold press [24] }\end{array}$ & Soxlet Extraction [24] & Cold Pressing [24] \\
\hline Lauric (C12:0) & 0.02 & - & - & - & - \\
Myristic (C14:0) & 0.37 & 0.21 & 0.41 & 1.09 & 0.63 \\
Pentadecanoic (C15:0) & 0.10 & - & - & - & - \\
Palmitic (C16:0) & 24.18 & 20.27 & 24.99 & 34.73 & 34.89 \\
Palmitoleic (C16:1) & 0.16 & 0.23 & 0.4 & 0.19 & - \\
Margaric (C17:0) & 0.15 & 0.23 & - & - & 7.18 \\
Stearic (C18:0) & 3.52 & 5.35 & 6.85 & 4.45 & 40.58 \\
Oleic (C18:1) & 48.99 & 49.27 & 48.25 & 10.14 & 15.60 \\
Linoleic (C18:2) & 21.09 & 23.19 & 18.28 & 0.37 & - \\
Linolenic (C18:3) & 0.86 & 0.94 & 0.83 & - & - \\
Arachidic (C20:0) & 0.21 & - & - & - & - \\
Gondoic (C20:1) & 0.23 & - & - & - & - \\
Docosanoic (C22:0) & 0.03 & - & - & - & - \\
Erucic (C22:1) & 0.07 & - & - & - & - \\
Docosahexaenoic (C22:6) & 0.02 & - & - & - & - \\
Tetracosanoic (C24:0) & 0.04 & - & - & - & - \\
\hline
\end{tabular}

Furthermore, with the application of Viscozyme L on oil extraction, the resulted oil obtained three more unsaturated fatty acids, gondoic, erucic and docosahexaenoic (0.23, 0.07 and $0.02 \%$, respectively), as compared to other published reports. With the presence of DHA, it showed that the extraction method in this study contributed positively in polyunsaturated fatty acids. In general, the Gac oil extracted by the method in this study was rich in unsaturated fatty acids and contained lower percentage of saturated fatty acids. Other findings on Gac oil showed similar results [24], [27].

\section{Conclusion}

In conclusion, the $\%$ oil recovery and total carotenoid content in this study were significantly affected by enzyme concentration $(\% \mathrm{E} / \mathrm{S})$, incubation time, drying temperature.

With increasing enzyme concentration and incubation time, $\%$ oil recovery and total carotenoid content also increased. However, the \% oil recovery and total carotenoid content were varied with different drying temperatures. Finally, results illustrated that the optimal conditions for Gac aril oil extraction were $0.15 \% \mathrm{E} / \mathrm{S}$ enzyme concentration, 100 min incubation time and drying temperature $60^{\circ} \mathrm{C}$. Under these conditions, the oil recovery rate and total carotenoid content were $96.39 \%$ and $196.47 \mathrm{mg} / 100 \mathrm{~g}$, respectively. The quality of oil resulted from this study was investigated based on the peroxide value $(8.73 \mathrm{meqO} 2 / \mathrm{kg})$ and free fatty acid value $(3.58 \mathrm{mg} \mathrm{KOH} / \mathrm{g}$ oil), both of them were suitable to the Codex STAN 19-1981 standard for vegetable oil. In term of fatty acid composition, the higher \% unsaturated fatty acids (71.38\%) was obtained in comparison with the lower \% saturated fatty acids $(28.62 \%)$. The dominant fatty acids were oleic and linoleic acid (48.99\% and $21.09 \%$, respectively).

\section{References}

[1] Vuong, L. T., Dueker, S. R., \& Murphy, S. P. (2002). Plasma $\beta$-carotene and retinol concentrations of children increase after a 30-d supplementation with the fruit Momordica cochinchinensis (Gac). The American Journal of Clinical Nutrition, 75(5), 872-879.

[2] Aoki, H., Kieu, N. T. M., Kuze, N., Tomisaka, K., \& Chuyen, N. V. (2002). Carotenoid pigments in GAC fruit (Momordica cochinchinensis Spreng). Bioscience, Biotechnology, and Biochemistry, 66(11), 2479-2482.

[3] Ishida, B. K., Turner, C., Chapman, M. H., \& McKeon, T. A. (2004). Fatty acid and carotenoid composition of Gac (Momordica cochinchinensis Spreng) fruit. Journal of Agricultural and Food Chemistry, 52(2), 274-279. 
[4] Tuyen, C. K., Phan-Tai, H., \& Nguyen, M. H. (2014). Effects of pre-treatments on the yield and carotenoid content of Gac oil using supercritical carbon dioxide extraction. Journal of Food Engineering, 120, 44-49.

[5] Tuyen, C. K., Nguyen, M. H., Roach, P. D., \& Stathopoulos, C. E. (2013). Effects of Gac aril microwave processing conditions on oil extraction efficiency, and $\beta$-carotene and lycopene contents. Journal of Food Engineering, 117(4), 486491.

[6] Nhung, D. T. T., Bung, P. N., Ha, N. T., \& Phong, T. K. (2010). Changes in lycopene and beta carotene contents in aril and oil of gac fruit during storage. Food Chemistry, 121(2), 326-331.

[7] Kubola, J., Meeso, N., \& Siriamornpun, S. (2013). Lycopene and beta carotene concentration in aril oil of gac (Momordica cochinchinensis Spreng) as influenced by aril-drying process and solvents extraction. Food Research International, 50(2), 664-669.

[8] Vuong, L. T., Franke, A.A., Custer, L.J., Murphy, S.P. (2006). Momordica cochinchinensis Spreng. (gac) fruit carotenoids reevaluated. Journal of Food Composition and Analysis, 19(67), 664-668.

[9] Lenucci, M. S., De Caroli, M., Marrese, P. P., Iurlaro, A., Rescio, L., Böhm, V., Dalessandro, G., \& Piro, G. (2015). Enzyme-aided extraction of lycopene from high-pigment tomato cultivars by supercritical carbon dioxide. Food chemistry, 170, 193-202.

[10] Sharma, R., Sharma, P. C., Rana, J. C., \& Joshi, V. K. (2015). Improving the olive oil yield and quality through enzymeassisted mechanical extraction, antioxidants and packaging. Journal of Food Processing and Preservation, 39(2), 157-166.

[11] Latif, S., \& Anwar, F. (2009). Physicochemical studies of hemp (Cannabis sativa) seed oil using enzyme-assisted coldpressing. European Journal of Lipid Science and Technology, 111(10), 1042-1048.

[12] Barzana, E., Rubio, D., Santamaria, R. I., Garcia-Correa, O., Garcia, F., Ridaura Sanz, V. E., \& López-Munguía, A. (2002). Enzyme-mediated solvent extraction of carotenoids from marigold flower (Tagetes erecta). Journal of Agricultural and Food Chemistry, 50(16), 4491-4496.

[13] Dominguez, H., Nunez, M. J., \& Lema, J. M. (1993). Oil extractability from enzymatically treated soybean and sunflower: range of operational variables. Food Chemistry, 46(9), 277-284.

[14] Dominguez, H., Nunez, M. J., \& Lema, J. M. (1995). Enzymeassisted hexane extraction of soya bean oil. Food Chemistry, 54(2), 223-231.

[15] Cenkowski, S., Yakimishen, R., Przybylski, R., \& Muir, W. E. (2006). Quality of extracted sea buckthorn seed and pulp oil. Canadian Biosystems Engineering, 48(3), 9-16.
[16] Dominguez, H., Nunez, M. J., \& Lema, J. M. (1994). Enzymatic pretreatment to enhance oil extraction from fruits and oilseeds: a review. Food Chemistry, 49(3), 271-286.

[17] Mai, H. C., Truong, V., \& Debaste, F. (2013). Optimization of enzyme aided extraction of oil rich in carotenoids from $\mathrm{Gac}$ fruit (Momordica cochichinensis Spreng.). Food technology and biotechnology, 51(4), 488-499.

[18] Danso-Boateng, E. (2011). Effect of enzyme and heat pretreatment on sunflower oil recovery using aqueous and hexane extractions. Journal of Engineering Technology, 5(8), 662-668.

[19] Sosulski, K., Sosulski, F. W., \& Coxworth, E. (1988). Carbohydrase hydrolysis of canola to enhance oil extraction with hexane. Journal of the American Oil Chemists' Society, 65(3), 357-361.

[20] Rocha, R. P., de Castro Melo, E., de Almeida Barbosa, L. C., \& Radünz, L. L. (2011). Effect of drying air temperature upon the essential oil content of Mikania glometa. African journal of Food Science and Technology, 2(8), 184-188.

[21] Asoiro, F. U. a. C. O. A. (2011). Effect of temperature on oil extraction of Jatropha curcas L. kernel. Pacific Journal of Science and Technology, 12(2), 456-463.

[22] Boon, C. S., McClements, D. J., Weiss, J., \& Decker, E. A. (2010). Factors influencing the chemical stability of carotenoids in foods. Critical Reviews in Food Science and Nutrition, 50(6), 515-532.

[23] Santos, O. V., Corrêa, N. C. F., Soares, F. A. S. M., Gioielli, L. A., Costa, C. E. F., \& Lannes, S. C. S. (2012). Chemical evaluation and thermal behavior of Brazil nut oil obtained by different extraction processes. Food Research International, $47(2), 253-258$.

[24] Kha, T. C., Nguyen, M. H., Roach, P. D., \& Stathopoulos, C. E. (2014). Effect of drying pre-treatments on the yield and bioactive content of oil extracted from Gac aril. International Journal of Food Engineering, 10(1), 103-112.

[25] Tasan, M., Gecgel, U., \& Demirci, M. (2011). Effects of storage and industrial oilseed extraction methods on the quality and stability characteristics of crude sunflower oil (Helianthus annuus L.). Grasas y aceites, 62(4), 389-398.

[26] Jung, G. W., Kang, H. M., \& Chun, B. S. (2012). Characterization of wheat bran oil obtained by supercritical carbon dioxide and hexane extraction. Journal of Industrial and Engineering Chemistry, 18(1), 360-363.

[27] Thuat, B. Q. (2012). Research on extraction technology to improve yield and quality of oil from gac aril (Momordica cochinchinensis Spreng L.). Journal of Science and Technology, 48(1), 81-85. 